\title{
EFFECT OF MISTING ON THE MILK PRODUCTION OF FRIESIAN CROSSBRED DAIRY CATTLE
}

\author{
Al-Soaly, I. S. A. ${ }^{1}$, A. M. M. Ellithy ${ }^{2}$, R. R. El-Bessoumy ${ }^{3}$, \\ and M. M. M. Abd-Elkareem ${ }^{4}$
}

\section{ABSTRACT}

This work was carried out in the animal production research station in Gemmayzeh, Tanta, Al-Gharbia Governorate. The experimental part was during the summer, July and August season of 2015. Twenty-four dairy cattle were selected to the treatment, they were divided to two groups, twelve cows per group. Two cooling systems (Micro Sprinkler System (MSS), Fogger Sprinkler System (FSS)) were used in this work. The main objectives of this work were studying the effect of providing adequate shade on heat stress and milk production of dairy cattle to meet the demands of a small and medium-sized primitive farms for the production of milk, studying some engineering factors affecting the performance of the designed cooling system and to determine the effect of spraying by the designed cooling system and providing adequate shade for dairy cattle at pre-milking automated stage on the production of milk. The obtained results indicated that using the runtime periods of 1.5, 3, and 4.5min. per 15 min., without using a shelter reducing rate of ambient temperatures by 5, 5.9, and $6.4^{\circ} \mathrm{C}$ compared with 1.9, 3.6, and 5.7 $\mathrm{C}$ for MSS, and FSS, respectively. While, by using a shelter, the reducing rate of ambient temperatures by 5.2, 6.1, and $9.4^{\circ} \mathrm{C}$ compared with $1.9,3.7$, and $3.8^{\circ} \mathrm{C}$ for MSS, and FSS, respectively. From these pervious results the runtime period of 4.5/15min. was chosen for cooling the cattle. by applying this run time period on animals twice, four, and six times before milking, the milk producing was increased by $1.4 \%(0.6 \mathrm{~kg}), 1.96 \%(0.9 \mathrm{~kg})$, and $11.57 \%$ (5.6kg) compared with the morning production, respectively. Therefore, the runtime period of $4.5 / 15 \mathrm{~min}$. must be used for cooling the animals six time before milking.

\footnotetext{
${ }^{1}$ Prof. of Agric. Eng., Faculty of Agric. Eng. Cairo, Al-Azhar Univ.

2 Prof. of Agric. Eng., Agric. Eng. Dept., Faculty of Agric. Assuit, Al-Azhar Univ.

${ }^{3}$ Associate Prof. of Agric. Eng., Faculty of Agric. Eng. Cairo, Al-Azhar Univ.

${ }^{4}$ Eng. of Agric. Eng., Agric. Eng. Dept., Faculty of Agric. Assuit, Al-Azhar Univ.
} 


\section{INTRODUCTION}

$\mathrm{D}$ airy is the primary source for animal protein. Unquestionably, proteins are required in the human diet, for growth, development, and maintenance of human health. In Egypt, dairy is considered a cheaper animal protein sources compared to other animal protein sources such as meat. So, must combine the efforts of all the state institutions for the promotion of livestock projects especially that Egypt has favorable climatic conditions and the possibilities that promote the future of animal production. Heat stress is one of the greatest challenges faced by dairy farmers. It is a very important factor that reduces milk production in dairy cows. Indeed, up to $10 \%$ of the variability in milk production has been attributed to the effect of climatic factors such as temperature. The heat stress as a condition that occurs when an animal cannot dissipate an adequate quantity of heat, whether it is produced or absorbed by the body, to maintain body thermal balance (Bernabucci, et al. 2014). also, a heat stress period can be defined as days on which minimal air temperature is around $20^{\circ} \mathrm{C}$ and maximum air temperature is at least $31^{\circ} \mathrm{C}$, together with an air humidity level higher than 60\% (Noordhuizen and Bonnefoy 2015). The milk production was influenced by different thermal conditions, with a decrease during warmer months in non-cooled animals. (Titto, et al. 2013). The heat stress occurs when any combination of environmental conditions causes the effective temperature of the environment to be higher than the animal's thermo neutral (comfort) zone. Four environmental factors influence effective temperature: air temperature, relative humidity, air movement and solar radiation. When the temperature exceeds $27^{\circ} \mathrm{C}$, even with low humidity the effective temperature is above the comfort zone for high producing dairy cows (Armstrong 1994). The heat stress in warm environments is one of the major factors that can negatively affect milk production, reproduction, and the health of dairy cows Bernabucci, et al. (2010). The heat stress reduced daily milk yield by $1.32 \mathrm{~kg}$ or $9.46 \%$, by $0.92 \mathrm{~kg}$ or $9.62 \%$ and by $1.27 \mathrm{~kg}$ or $9.48 \%$ as the THI values went from 64 in the spring, from 66 in the autumn and from 42.34 in the winter periods to 79 in the summer period. (Könyves, et al. 2017). The temperature humidity index (THI) values were calculated as described by Thom (1959):

$$
\text { THI }=[(\% R H) / 100](T-14.4)+(0.8)(T)+46.6
$$


Where: $\% \mathrm{RH}=$ Percent relative humidity, $\mathrm{T}=$ Current air temperature in ${ }^{\circ} \mathrm{C}$. Curtis, et al. (2017).

Therefore, the aim of this work is to reduce the thermal stress within holding area to increase milk production during the summer months. The holding area is usually the most stressful area for dairy cattle in hot weather especially in the primitive corrals.

\section{MATERIALS AND METHODS}

To achieve objectives of the present work, the following steps had been taken into consideration: (1) A primitive farm, open system, was chosen for dairy cattle. This type of cattle sheds was the most economical and common in Egypt. (2) The average milk production was recorded for the chosen dairy cattle farm. (3) A random sample was selected to represent half of the herd. This means that dairy cattle were divided into two groups. The first group was milked as it's customary without using the cooling system inside the holding area. The other group was milked after using the cooling system within the holding area. 4 . The simple cooling was a system Assembled to fit cooling operation within the holding area. the following points were taken: (a) The natural ventilation and prevailing winds were taken as much as possible as advantage when the system was installed to maximizing their effectiveness. (b) The cooling system must be characterized simplicity of composition to maintenance easily and reduce operating costs. (5) The final experiments were carried out to study the effect of spraying animal's inside the holding area on average milk production. 1. The animals: Twenty-Four Friesian crossbred were used in this study. Average live body weight $485.2 \pm 9 \mathrm{~kg}$ (LBW), the experimental animals were divided into two groups (each of 12 animals). the first group were exposed to be cooled under cooling systems, while those in the second group were kept under the normal climatic conditions of summer in the farm. The animals were fed on concentrated feed, rice straw and silage once daily only at (10:00 am). according to their live body weight (LBW).

2. Corral of cattle: Cows were housed in open dry lot corrals. The corral was accommodated to 24 cows $\left(16.5 \mathrm{~m}^{2} / \mathrm{cow}\right)$. The corral wall was represented in a steel fence, height of $1.6 \mathrm{~m}$. The cows had a free access to drinking water in the corral. 
3. The holding area: holding area was located near the milk parlor. Two doors to enter the milk parlor were located on the end of the holding area. Holding area was divided into two parts, (a) the first part was a concrete flat land and it had a door to enter the cows. Width of $8.5 \mathrm{~m}$ and length of $6 \mathrm{~m}$. were the first part dimension (b) the second part was formed from concrete with slope $8 \%$. Width of $8.5 \mathrm{~m}$ and length of $10 \mathrm{~m}$. were the second part dimension. It was used to installation of the simple cooling system to achieve the objectives of this research. The holding area accommodated of 34 cows $\left(2.5 \mathrm{~m}^{2} / \mathrm{cow}\right)$. The longitudinal axis of the holding area was aligned on (North - South) direction. The main frame of the holding area was made from metal. The frame dimensions of $40 \times 40 \mathrm{~mm}$., the holding area constructions dimensions were $9500 \times 8500 \times 3000 \mathrm{~mm}$. Holding area was covered with single layer of polyethylene plastic of (120 $\mu \mathrm{m}$ thick). These plastic film materials were commonly used as a greenhouse covers and shading. 4. Milking parlor: the width of $6 \mathrm{~m}$, length of $14 \mathrm{~m}$ and height of $3.6 \mathrm{~m}$. were the milk parlor dimensions. Milk parlor contained $(2 \times 8)$ herringbone lounges. 5. Cooling systems: Two major concepts were used to fabricate the simple cooling system for holding area,

- coverage of holding area by using shelter to provide adequate shade and protect from solar radiation.

- installation of sprinkler system to increase the evaporative cooling of the cows.

Two cooling systems were used in this study: (a) Micro-jet Sprinklers System (MSS), Fogger Sprinkler System (FSS). (b) Runtime set for each sprinkler cycle: three runtimes set were used for each sprinkler cycle (1.5, 3 and $4.5 \mathrm{~min}$ per $15 \mathrm{~min}$ ) to study the effect of the operating time on average milk production. (c) The shelter: The performance of cooling systems was tested with and without the shelter to study the effect of the shading on temperature and humidity.

5.1 Components of the cooling systems: (1) A booster pump: A centrifugal water pump was used for providing the pressure which needed to operate the cooling system. The technical specifications of the cooling systems are: 


\begin{tabular}{|l|c|}
\hline The pump model & $\begin{array}{c}\text { Calpeda S.P.A \& N.G.M } 4 \\
230 \pm 10 \% \text { volt } ~ 50 \mathrm{~Hz}: 5.7 \mathrm{~A}\end{array}$ \\
\hline Manufacturing country & Italy \\
\hline Power $(\mathrm{Kw})$ & $0.75 \mathrm{Kw}(1 \mathrm{bar})$ \\
\hline Discharge $\left(\mathrm{m}^{3} / \mathrm{hr}.\right)$ & $0.25: 4$ \\
\hline Pumping head generated $(\mathrm{m})$ & 22 \\
\hline
\end{tabular}

(2) the used pipelines of the cooling system were PVC plastic, the diameter of main line, was $25.4 \mathrm{~mm}$. The diameter of lateral lines was $16 \mathrm{~mm}$. and made of Poly-ethylene usually. (3) Nozzles: Two types of nozzles were chosen to operate within the cooling system. (a) Micro-jet sprinkler: its radius reaches to 6 meters depending on the pressure. Its discharges ranged from 0.025 to $0.400 \mathrm{~m}^{3} \mathrm{hr}$. Recommended spacing ranging from 0.5 to $5 \mathrm{~m}$. recommended pressure ranging from $1 \mathrm{~kg} / \mathrm{cm}^{2}$ to $3.5 \mathrm{~kg} / \mathrm{cm}^{2}$ (0.98 to 3.43 bar). in this study had a flow rate about $0.357 \mathrm{gpm}$ (1.35 liters/min) with typically throw diameter $3.8 \mathrm{~m}$ at $1.019 \mathrm{~kg} / \mathrm{cm}^{2}$ (1 bar) pressure. (b) Fogger Sprinkler: Recommended working pressure ranging from 2 to $4 \mathrm{~kg} / \mathrm{cm}^{2}$ (1.96 to 3.92 bar). the distance between laterals 2 to $3 \mathrm{~m}$. and $1.5 \mathrm{~m}$ between heads. The flow rate ranging from 20 to $28 \mathrm{Liter} / \mathrm{hr}$. which depending on operating pressure. The fogger sprinkler used in this work had a flow rate about $0.04 \mathrm{gpm}(0.14$ liters $/ \mathrm{min})$ with typically throw diameter $1.8 \mathrm{~m}$ at 1.019 bar.

6. High accuracy Thermo-Hygro: This device was used to measure ambient relative humidity (R.H.\%).

7. Experiments Variables: The experiments Variables were: type of the cooling system, runtime of sprinkler cycle, and shading.

8. Measurements: All of measurements were taken twice daily on (5:30 am) and $(4: 30 \mathrm{pm})$ which the milking process was taken place in these periods. (a) Meteorological data: the values of temperature $\left({ }^{\circ} \mathrm{C}\right)$ and relative humidity (\%) were recording during the experimental period. Ambient temperature was measured by using mercurial. thermometer (accuracy $1^{\circ} \mathrm{C}$ ). The ambient relative humidity was measured before and after spraying by using High Accuracy Thermo-Hygro device (accuracy 1\%). (b) Rectal temperature: Rectal temperature was measured manually at 
morning and afternoon before and after spraying using mercury thermometer (accuracy $0.1^{\circ} \mathrm{C}$ ). (c) Milk production: Milk production was estimated twice daily at 5:30 AM and 4:30 PM, automatically by using automated milking machine as shown in Figure (3.14). where amounts of milk were collected in a jar of glass with capacity $28 \mathrm{~kg}$. it was divided every $0.1 \mathrm{~kg}$.

\section{RESULTS AND DISCUSSIONS}

The following items declare the effect of different cooling systems on (THI) temperature humidity index.

1. Effect of using the different cooling systems on Temperature Humidity Index (THI) at (4:30 pm): Fig. (1) shows that the maximum reduction rate in THI value was 7.64, when the MSS cooling system used at runtime of $4.5 / 15 \mathrm{~min}$ with shelter. So, that system was selected for animals and record the effect of cooling on the total milk production.

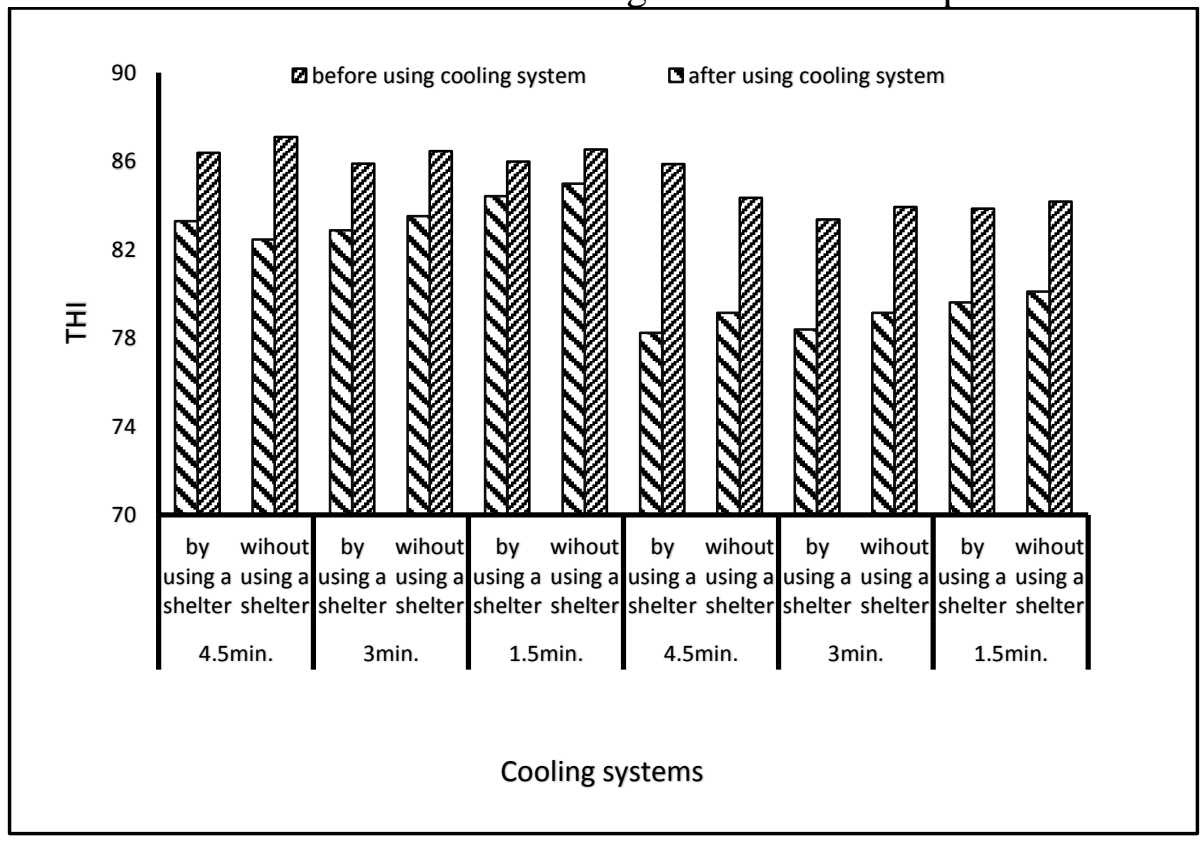

Fig. (1): Effect of using different cooling systems on temperature humidity index (THI).

2. Average rectal temperature for both groups without using any cooling system (at 4:30 pm) during the experimental days.

Table (1): shows the rectal temperatures average and total milk productions for both groups without using any cooling system during the experimental 
days at $(4: 30 \mathrm{pm})$. The data in Table (1) shows that rectal temperatures average for the first group were ranged from $38.4^{\circ} \mathrm{C}$ to $40.2^{\circ} \mathrm{C}$ compared with $38.2^{\circ} \mathrm{C}$ to $40.1{ }^{\circ} \mathrm{C}$ for the second group during experimental days. Maximum rectal temperatures average was ranged from 38.9 to $40.2^{\circ} \mathrm{C}$ for the first group, compared with 38.9 to $40.1^{\circ} \mathrm{C}$ for the second group. These results indicate to the homogenization between animal's body temperature, which indicates the good health status of animals. Total milk productions for the first group were ranged from $34.1 \mathrm{~kg}$ to $44.8 \mathrm{~kg}$ during the experimental days, compared with $22 \mathrm{~kg}$ to $36.2 \mathrm{~kg}$ for the second group during the experimental days.

\begin{tabular}{|c|c|c|c|c|}
\hline \multirow{2}{*}{$\begin{array}{l}\text { Experimental } \\
\text { days }\end{array}$} & \multicolumn{2}{|c|}{$\begin{array}{c}\text { First group } \\
\text { (cooled group) }\end{array}$} & \multicolumn{2}{|c|}{$\begin{array}{c}\text { Second group } \\
\text { (controlled group) }\end{array}$} \\
\hline & $\begin{array}{l}\text { Range of } \\
\text { R.T. }\left({ }^{\circ} \mathrm{C}\right)\end{array}$ & $\begin{array}{l}\text { Total milk } \\
\text { pro. }(\mathrm{Kg})\end{array}$ & $\begin{array}{l}\text { Range of } \\
\text { R.T. }\left({ }^{\circ} \mathrm{C}\right) \\
\end{array}$ & $\begin{array}{l}\text { Total milk } \\
\text { pro. }(\mathrm{Kg})\end{array}$ \\
\hline $20 / 07 / 2015$ & $38.9-39.8$ & 35.2 & $38.6-39.8$ & 29.6 \\
\hline $21 / 07 / 2015$ & $38.6-40$ & 43 & $38.2-39.7$ & 36.2 \\
\hline $22 / 07 / 2015$ & $38.9-40$ & 41.4 & $38.5-39.7$ & 24 \\
\hline $23 / 07 / 2015$ & $38.9-40$ & 36.5 & $38.7-39.7$ & 33.3 \\
\hline $24 / 07 / 2015$ & $38.5-40.1$ & 44.1 & $38.2-39.7$ & 28.1 \\
\hline $25 / 07 / 2015$ & $39-40$ & 42.2 & $38.4-39.8$ & 26.6 \\
\hline $26 / 07 / 2015$ & $38.4-39.3$ & 37.1 & $38.5-39.7$ & 27.2 \\
\hline $27 / 07 / 2015$ & $38.9-40.2$ & 43.6 & $38.9-40.1$ & 27.6 \\
\hline $28 / 07 / 2015$ & $38.5-40$ & 42 & $38.5-40$ & 35.1 \\
\hline $29 / 07 / 2015$ & $39-40.1$ & 34.1 & $38.8-40$ & 22 \\
\hline $30 / 07 / 2015$ & $38.6-40.1$ & 44.7 & $39-40$ & 30.9 \\
\hline $31 / 07 / 2015$ & $39-40$ & 42.8 & $38.5-40$ & 25.7 \\
\hline $01 / 08 / 2015$ & $38.4-40.1$ & 39.5 & $38.7-40.1$ & 23.7 \\
\hline 02/08/2015 & $39-40$ & 43.2 & $38.8-40$ & 30.7 \\
\hline $03 / 08 / 2015$ & $39-40.1$ & 44.6 & $38.9-40$ & 28.6 \\
\hline $04 / 08 / 2015$ & $38.9-40$ & 44.8 & $38.8-39.9$ & 28.8 \\
\hline $05 / 08 / 2015$ & $38.9-40$ & 42.6 & $38.9-40$ & 30 \\
\hline $06 / 08 / 2015$ & $38.6-40$ & 45.8 & $38.9-40.1$ & 34.3 \\
\hline $07 / 08 / 2015$ & $38.9-39.8$ & 48.4 & $38.9-40$ & 24.1 \\
\hline
\end{tabular}




\section{Average rectal temperature and total milk production for the first} group (cooled group) compared with the second group (controlled group) with the different runtime periods after using MSS cooling system (at 4:30 p.m.).

Table (2): shows the average rectal temperatures and total milk productions for both groups by using MSS cooling system.

The data in table (2) shows The rectal temperatures average ranged from $38.9^{\circ} \mathrm{C}$ to $40^{\circ} \mathrm{C}$ before using MSS while the rectal temperatures average ranged from $38.6^{\circ} \mathrm{C}$ to $39.7^{\circ} \mathrm{C}$ after using MSS at runtime period of $1.5 / 15$ min. also, the total milk production of the first group was $43.2 \mathrm{~kg}$ compared with the total milk production of the second group which was $30.7 \mathrm{~kg}$ with increasing ratio $(12.5 \mathrm{~kg}) 28.9 \%$ of total milk production. While The rectal temperatures average ranged from $39^{\circ} \mathrm{C}$ to $40.1^{\circ} \mathrm{C}$ before using MSS while the rectal temperatures average ranged from $38.6^{\circ} \mathrm{C}$ to $39.8^{\circ} \mathrm{C}$ after using MSS at runtime period of $3 / 15 \mathrm{~min}$. also, the total milk production of the first group was $44.6 \mathrm{~kg}$ compared with the total milk production of the second group which was $28.6 \mathrm{~kg}$ with increasing ratio $(16 \mathrm{~kg}) 35.87 \%$ of total milk production. The rectal temperatures average ranged from $39^{\circ} \mathrm{C}$ to $40^{\circ} \mathrm{C}$ before using MSS while the rectal temperatures average ranged from $38.6^{\circ} \mathrm{C}$ to $39.6^{\circ} \mathrm{C}$ after using MSS at runtime period of $4.5 / 15 \mathrm{~min}$. also, the total milk production of the first group was $44.8 \mathrm{~kg}$ compared with the total milk production of the second group which was $28.8 \mathrm{~kg}$ with increasing ratio $(16 \mathrm{~kg}) 35.71 \%$ of total milk production. These results indicated that runtime period of $4.5 / 15 \mathrm{~min}$. has been selected for cooling animals which gives allow rate of ambient temperature by $9.4 \mathrm{C}$ and relative humidity $26.9 \%$ after using MSS cooling system.

\begin{tabular}{|c|c|c|c|c|c|}
\hline \multicolumn{4}{|c|}{ First group (Cooled group) } & \multicolumn{2}{|c|}{$\begin{array}{c}\text { Second group } \\
\text { (Controlled group) }\end{array}$} \\
\hline \multirow[b]{2}{*}{$\begin{array}{l}\text { Runtime } \\
\text { periods }\end{array}$} & \multicolumn{2}{|c|}{ Rectal temp. $\left({ }^{\circ} \mathrm{C}\right)$} & \multirow{2}{*}{$\begin{array}{c}\text { Total } \\
\text { milk } \\
\text { pro. } \\
(\mathrm{kg})\end{array}$} & \multirow[b]{2}{*}{$\begin{array}{c}\text { Rectal } \\
\text { temp. }\left({ }^{\circ} \mathrm{C}\right)\end{array}$} & \multirow{2}{*}{$\begin{array}{c}\text { Tota } \\
\text { milk } \\
\text { pro. } \\
(\mathrm{kg})\end{array}$} \\
\hline & $\begin{array}{c}\text { Before } \\
\text { using } \\
\text { MSS }\end{array}$ & $\begin{array}{l}\text { After using } \\
\text { MSS }\end{array}$ & & & \\
\hline $1.5 / 15 \mathrm{~min}$ & $38.9-40$ & 38.6 & 43.2 & $38.8-40$ & 30.7 \\
\hline $3 / 15 \min$ & $39-40.1$ & $38.6-39.8$ & 44. & $38.9-40$ & 28.6 \\
\hline $4.5 / 15 \mathrm{~min}$ & $39-40$ & $38.6-39.6$ & 44.8 & $38.8-39.9$ & 28.8 \\
\hline
\end{tabular}




\section{Effect of repetition runtime period $(4.5 / 15 \mathrm{~min})$ on average rectal temperature and total milk production.}

Fig (2) shows that in cooled group, the total milk production increased at runtime period of $4.5 / 15 \mathrm{~min}$. six times, the total milk production was 24.1 $\mathrm{kg}$ and increased to be $48.4 \mathrm{~kg}$ by increasing of $50.21 \%$ (24.3). the total milk production increased at runtime period of $4.5 / 15 \mathrm{~min}$. four times, the total milk production was $34.3 \mathrm{~kg}$ and increased to be $45.8 \mathrm{~kg}$ by increasing of $25.11 \%(11.5 \mathrm{~kg})$. The total milk production increased at runtime period of $4.5 / 15 \mathrm{~min}$. twice, the total milk production was $30 \mathrm{~kg}$ and increased to be $42.6 \mathrm{~kg}$ by increasing of $29.57 \%(12.6 \mathrm{~kg})$.

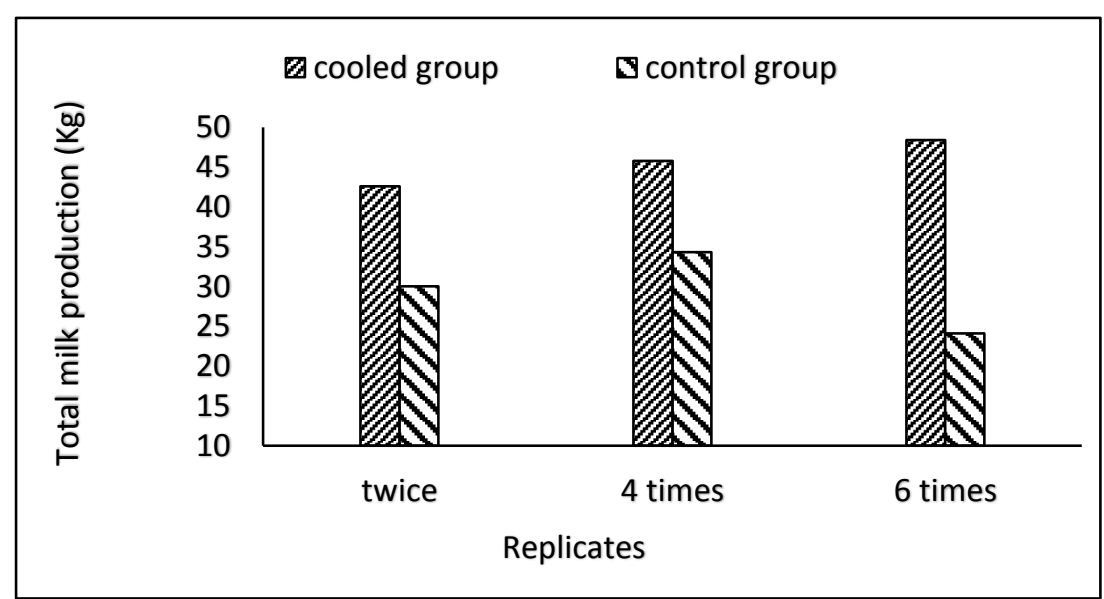

Fig. (2) Effect of repetition runtime period of (4.5/ 15min.) on total milk productions.

\section{CONCLUSION}

the results of this experimental work appeared that A simple cooling system can be used to meet the demands of small and medium-sized primitive farms to alleviate the heat stress in dairy cattle at pre-milking automated stage. It is useful in reducing rectal temperature at pre-milking automated stage and reducing the reduction in milk production due to exposure to heat stress during noon period by cooling cattle before afternoon milking for (4.5min/ $15 \mathrm{~min}$.) and replicate this period six times before milking by using Micro-Jet Sprinkler system (M.S.S.) to jet a favorable result. 


\section{REFERENCES}

Armstrong, D. V. (1994). Heat Stress Interaction with Shade and Cooling. J. Dairy Sci. (77):2044-2050.

Bernabucci, U., N. Lacetera, L. H. Baumgard, R. P. Rhoads, B. Ronchi, and A. Nardone, (2010). Metabolic and hormonal acclimation to heat stress in domesticated ruminants. Animal, 4(07), 1167-1183.

Bernabucci, U., S. Biffani, L. Buggiotti, A. Vitali, N. Lacetera and A. Nardone, (2014). The effects of heat stress in Italian Holstein dairy cattle. Journal of Dairy Science, 97(1):471-486, http://dx.doi.org/ 10.3168/jds.2013-6611.

Curtis, A.K., B. Scharf, P.A. Eichen, and D.E. Spiers, (2017). Relationships between ambient conditions, thermal status, and feed intake of cattle during summer heat stress with access to shade. Journal of Thermal Biology, (63): 104-111. http://dx.doi.org/10.1016/j.jtherbio.2016.11.015.

Könyves, T., N. Zlatković, N. Memiši, D. Lukač, N. Puvača, M. Stojšin, and B. Miščević, (2017). Relationship of temperature-humidity index with milk production and feed intake of Holstein-Friesian cows in different year seasons. The Thai Journal of Veterinary Medicine, 47(1), 15-23.

Noordhuizen, J., and J. M. Bonnefoy, (2015). Heat stress in dairy cattle: major effects and practical management measures for prevention and control. Symbiosis J. Vet. Sci, 1, 103-109.

Thom, E. C., (1959). The discomfort indexes. Weather-wise, 12(2), 57-61.

Titto, C. G., J. A. Negrão, E. A. L. Titto, T. S. Canaes, R. M. Titto, and A. M. F. Pereira, (2013). Effects of an evaporative cooling system on plasma cortisol, IGF-I, and milk production in dairy cows in a tropical environment. Int J Biometeorol 57(2):299 306. DOI: 10.1007/s00484-012-0554-6. 


\section{الملخص العربي \\ تأثير الترذيذ على إنتاج اللبن في ماثية الفريزيان الهجين \\ السؤالى. إ. س. أ'، أ. م. م. الليثيخ ، ر. ر. البسوميّ و م. م. م. م. عبدالكريم؛}

تم إجر اء التجارب في محطة بحوث الإنتاج الحيواني - بالجميزة ـ مركز طنطا - محافظة الغربية.

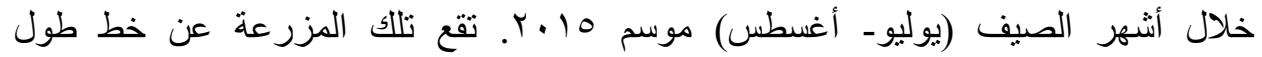

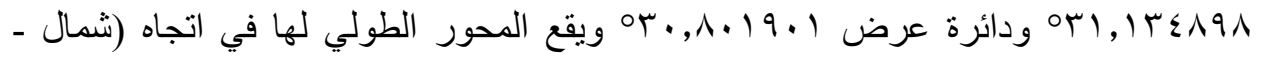
جنوب) وتعتبر مزرعة أبقار اللبن من النظام المفتوح وهي تشتمل على حظيرة واحده للرعي.

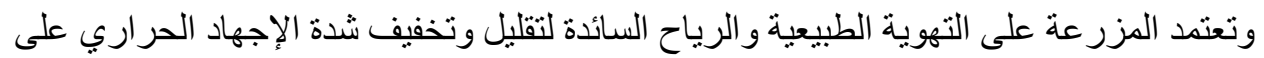

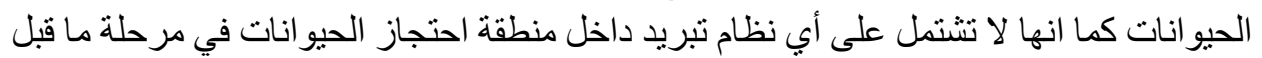

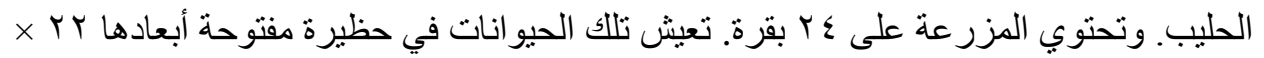

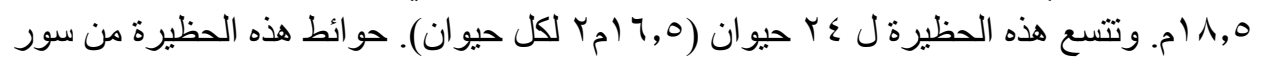

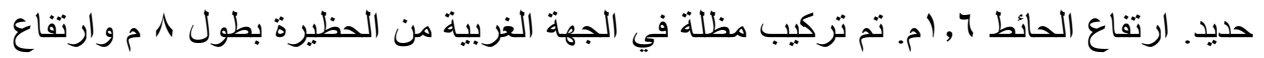

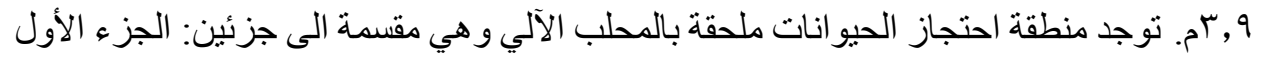

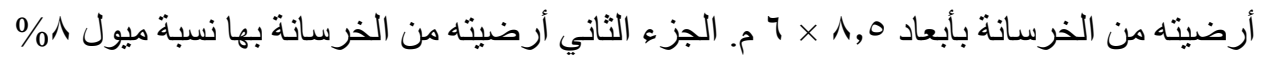

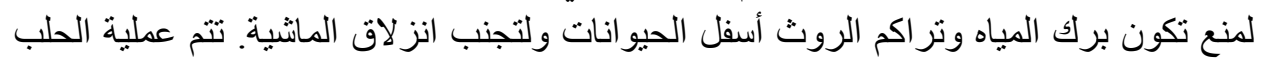

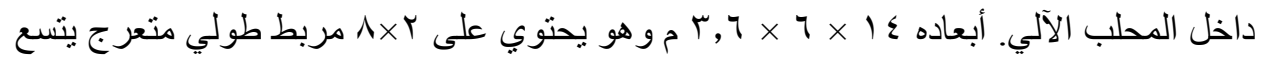

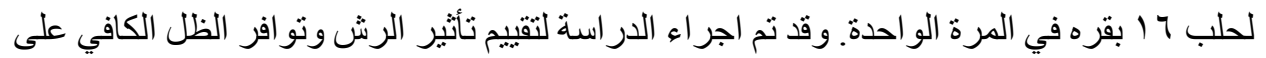
الإجهاد الحراري في للأبقار الحلوب و إنتاج الحليب. وذلك من خلال تصميم و اختبار نظام بسيط

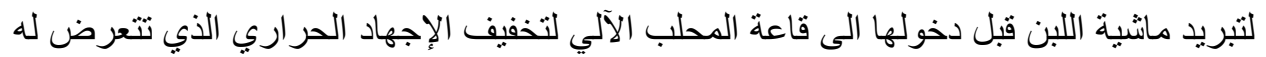

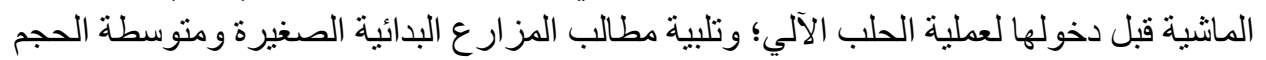
لإنتاج الحليب؛ دراسة بعض العوامل الهندسية التي تؤثر على أداء نظام التبريد البسيط؛ در اسة تأثير الرش باستخدام نظام التبريد البسيط مع تو افر الظل الكافي لأبقار اللبن في مرحلة ما قبل الحلب على إنتاج اللبن.

وقد أوضحت النتائج ما يلي:

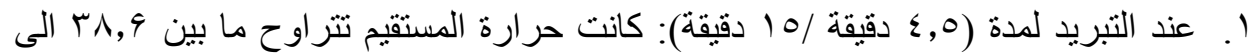

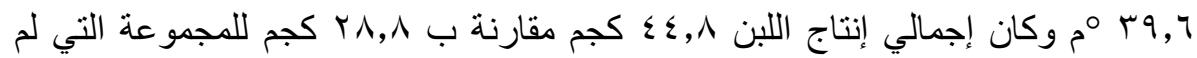
تتعرض للترذيذ بنسبة زيادة

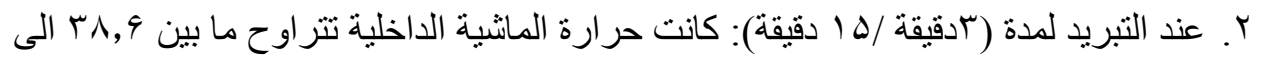

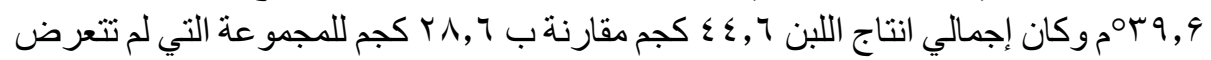
للترذيذ بنسبة زيادة $35.87 \%$ من إجمالي انتاج اللبن.

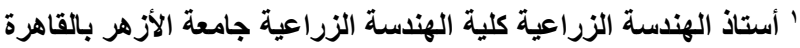

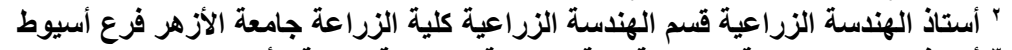

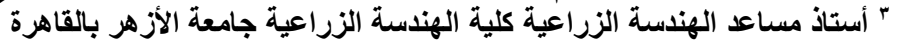

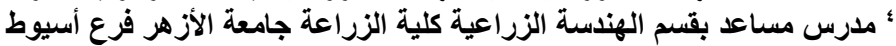




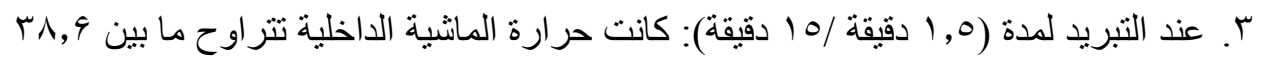

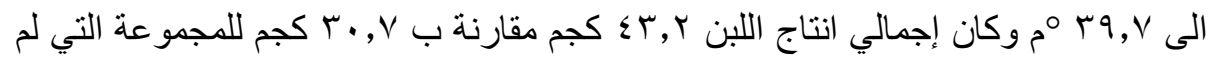
تتعرض للترذيذ بنسبة زيادة

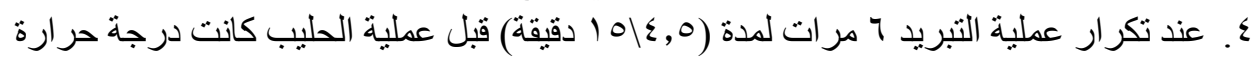

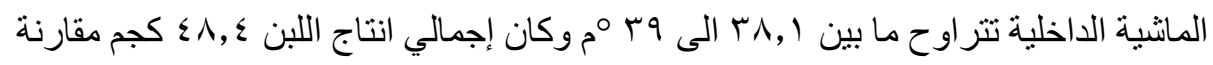

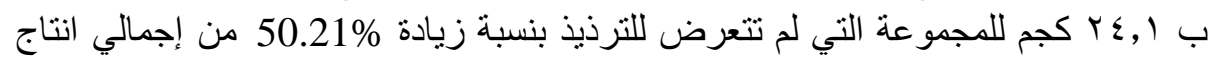

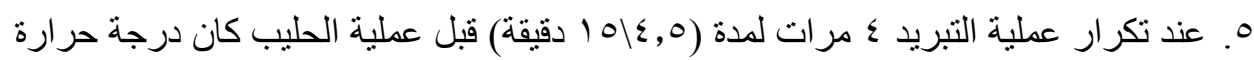

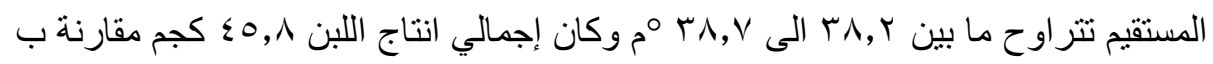

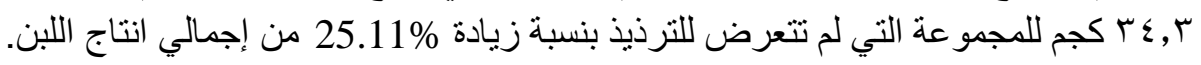

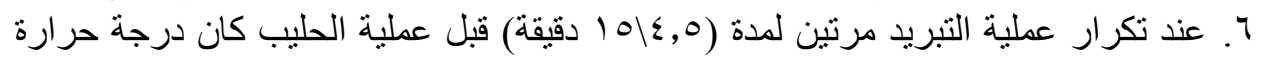

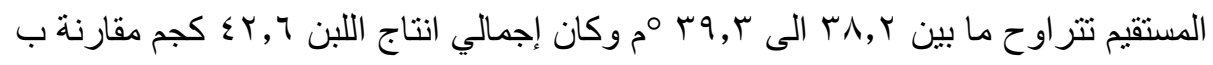
• ب كجم للمجموعة التي لم تتعرض للترذيذ بنسبة زيادة

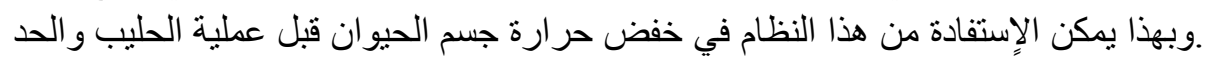

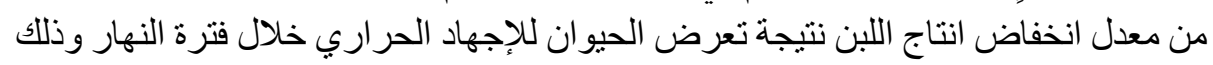

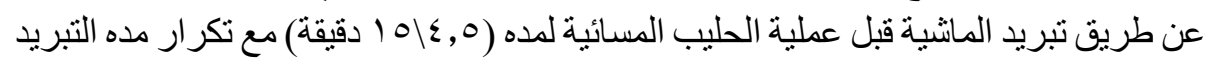
7 مر ات للحصول على نتائج مرضية. 